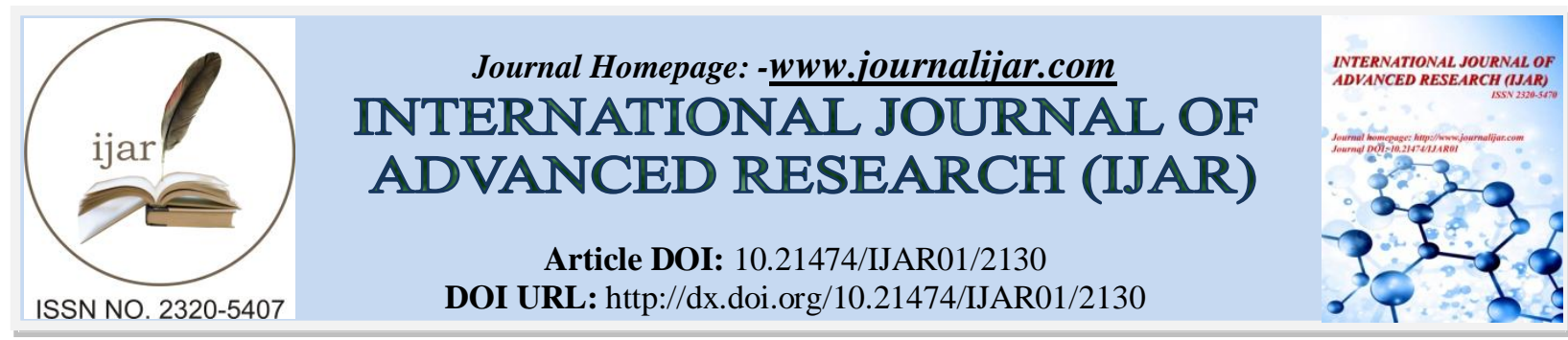

RESEARCH ARTICLE

\title{
A HOLISTIC VIEW TOWARDS THE BREAKING-OUT OF THE GLOBAL FINANCIAL CRISIS.
}

"Yingqin Huang ${ }^{1}$ and Siyuan Huang ${ }^{2}$.

1. The Finance Department, Beijing International Studies University, China.

2. Josef Korbel School of International Studies, University of Denver, USA.

\section{Manuscript Info}

Manuscript History

Received: 25 September 2016

Final Accepted: 27 October 2016

Published: November 2016

Key words:-

global financial crisis, economic, regulatory, political, ideological, sociological

\begin{abstract}
This article, taking a holistic view, proposed that such factors as economic, regulatory, political, ideological and sociological all contribute to the breaking-out of the global financial crisis. This study aims to reveal that the breaking-out of the global financial crisis is not just the matter of finance and economy, rather it is the result of the coordination of economic, regulatory, political, ideological, sociological, and so on. Thus in order to prevent the global financial crisis from breaking out, measures concerned with all these factors should be taken in advance.
\end{abstract}

Copy Right, IJAR, 2016,. All rights reserved.

\section{Introduction:-}

The global financial crisis in 2008 is considered to have been the worst scenario since the Great Depression, contributing to an economic downturn and global recession in the subsequent years. The causes that result in such a great disaster have been the great concern of economic scholars and experts. The economists Taleb and Blyth(2011) held that economy is a complex social system, in which many factors are mutually reinforced and co-contribute to the crisis.Based upon their points of view and other studies,this articletakes a holistic view, proposing that such factors as economic, regulatory, political, ideological and sociological are all involved, which will be discussed in the following, and in the meanwhilea brief discussion on how to avoid such crisis will be presented.

\section{Economic Factors:-}

Speculative Bubbles and High Rates of Leverage:-

One key economic factor has to do with the emergence of speculative bubbles in real estate and financial markets, which helps to create excess liquidity in markets and overconfidence on the part of regulators and investors that further encourages this kind of slack attitude towards risk assessment.

Keynes used "animal spirits" to describe how the psychological factor influences investors' confidence level. Behavioral economists employed "herd behavior" to explain the momentum in financial markets. Keynes (1973:114) said, "Knowing that our own individual judgment is worthless, we fall back on the judgment of the majority or the average." Skidelsky(2008)stated that under conditions of uncertainty, rational investors will fall back on "conventions", which gives them the assurance that they are doing the right thing, and that conventional behavior will easily turn into herd behavior. All these ideas help to interpret the investors and firms' seeming crazy behavior on every high rates of leverage.

In addition, just as Reinhart and Kenneth (2009) argued, the public may have a delusion: "this time is different", which convinced them that housing prices could only go up rather than go down. The fact that the public accept very 
high rates of leverage may further create a condition of fragility that characterized financial markets in so many countries. Furthermore, this big shift in expectations in turn created more acceptance of the idea that further leverage is good because "this time is different". Thus speculative bubbles and high rates of leverage, whose disastrous effect that the public ignored owing to "animal spirits" and "herd behavior" effects, are the main economic causes of the crisis.

\section{Imbalance in the Global Economy:-}

Another closely related factor has to do with the issue of imbalances created in global economy. During the 1980s,1990s, and early 2000s, the global economic imbalances were created in the contents of divergent road trajectory — some countries were growing very quickly while others weren't(Wade, 2008). Export-oriented countries were attracting large pools of foreign investments and became the magnets for capital created in liquid financial markets. The giant pool of capital which sought profitable investment activities or opportunities at the context of the booming expectations characterized so many economies during that period. The kinds of investment that ended up soaking up that pool of liquidity turned out to be highly non-transparent and highly risky, which aggravated problems of fragility of economy.

\section{Changes in the Structure of Banking System:-}

The third inevitable factor has rapport with changes in the structure of banking in many countries, particularly in wealthy countries. The emergence of the new model of banking in the late 80s, 90s, and early 2000s has to do with the changing strategy that shifts from originate-to-hold to originate-to-distribute(Wade, 2008; Crotty, 2009).

The old model, that is the pre-1980s model, worked in a very simple way; that is, banking was considered to be a kind ofslippy conservative industry. Bankers would make loans and remain these loans on their books, namely on their balance sheet, until they were repaid. Thisbanking service held up to 1980s.

In the 1980s, in the contents of deregulation of financial markets, bankers began to shift their activities to originate and distribute, which meant they were making loans as fast as they could, and thanks to the liquidity of markets, they had a large amount of capital that they could make loans against. However, instead of holding those loans, bankers were very quickly bundling up those loans and selling them. Those bundles of loans made up the collateralized debt obligations (CDOs) or the asset-backed securities (ABS). And that churning of loans also contributed to the fragility of the financial system, because these loans which were made very quickly without a lot of oversight, bundled up and sold, and then put it in new bundles and sold again and again, and eventually this giant packages of loans started to blow up, that is to say, a significant portion of that went into default. In the early stages of the financial crisis in 2007 and 2008, some of the loans, especially those related to the real estate, started to look like very risky bundles because of the high default rate. Obviously it is that change in the structure of banking that plays an important role in causing financial crisis.

\section{Failures of Credit Rating Industry and Its Operational Model:-}

Credit rating agencies (CRAs) work in a very peculiar fashion due to the unique structure of the market, which is often described as a duopoly because it is monopolized by two major firms - Moody's as well as Standard and Poor's (S\&P). Owing to the special business model, firms and governments have to pay these CRAs in order to be rated, which creates a kind of perverse incentive especially for the two big players to compete to attract clients by providing lower rating standards. Based on this perverse incentive model, part of the reason why the CRAs failed to rate all those $\mathrm{CDO}$ bundles is that the economic incentive under which the industry operates created a kind of pressure to have lowest possible standards rather than highest. Besides, these CRAs used Value-at Risk (VAR) models to rate the risks, which turned out not to have done a very good job of assessing risks because of the fundamental flaws in those models (Crotty, 2009:571).

Early in the global financial crisis in terms of this issue, there were lots of discussions about changing the credit rating industry in a very radical sense. A report made by the US congressional committee also suggested the idea of reforming CRAs so as to make CRAs operate more like public utilities which might prevent any more perverse incentive. So undeniably the failures and ethical deficiency of CRAs are part of the economic backdrops for the crisis. 


\section{Lack of Transparency of Particular Asset Classes:-}

From the late 1980s, assets such as derivatives and CDOs that are characterized by a lack of transparency had been actively traded and those asset markets became very chaotic. There wasno oversight that tries to ensure the transparency so that investors really knew what was in the bundles they were buying and how risky some of the derivative transactions they got involved in. Apparently this lack of transparency has a hand in the break-out of the global financial crisis.

\section{Overreaction of US Federal Reserve in 1987:-}

Thanks to the tight monetary policy, the US dollar had appreciated a lot from 1978 to 1985 , which turned out to be a political issue in the US by 1985 because of so many job losses in the export sector. So the late President Reagan called his counterparts to intervene in the value of dollar collectively by dumping dollar, which caused dollar to depreciate after 1985. However the US economy didn't improve and the trade performance got worse in late 1985, 1986 and 1987. During the mid-late 1980s, investors around the world were looking for further action by the G7 and particularly by the US to curve the US trade imbalances. When that didn't happen, investors became very discouraged about the US economy after 1987 and they sold large portfolios of dollars and dollar-based assets like stocks of US firms, which caused some stock markets fall into crisis in November of 1987. The Fed under the Chair Alan Greenspan reacted to that market crisis by beginning to loosen monetary policy in the expectation of preventing the downturn of the US economy in 1987 into a big recession and crisis. And in the subsequent 10 years from 1987, US monetary policy was quite loose, which created excess liquidity that contributed to speculative bubbles. So the strategy in the US monetary policy had a role in creating the economic conditions that led to the crisis.

\section{Increasing Tolerance to Debt on Individual Households:-}

Paralleling the emergence of a high degree of tolerance to leverage on the corporate sector and public sector, individual households that were access to large pools of credit at low cost appreciated all the loans they had during the $80 \mathrm{~s}, 90 \mathrm{~s}$, and early 2000s. So the average level of household indebtedness also rose alongside the corporate and public sector indebtedness, making household finances increasingly fragile as well. And that fragility again seems tolerable because "this time is different" mentality emerged in the context where households were enjoying rising wealth at least on paper as the bubbles were emerging in real estate and stock markets. Therefore many families felt wealthier because the value of their net wealth rose in the context of these assets bubbles, making them much more tolerant of taking higher and higher levels of debt.

However the household can never predict when the bubble is going to burst because it is fundamentally unknowable (Reinhart and Kenneth, 2009). As the "turkey problem" revealed, the confidence level is always the maximal at the onset of the financial crisis (Taleb and Blyth, 2011). Additionally, in terms of insights from Keynes and behavioral economists, we know that once a bubble bursts, the market will get a downward momentum that will create a kind of vicious cycle as we can see during the crisis.

\section{Regulatory Factors:- \\ Vicious Cycle Between Light Touch Regulation and Liquidity:-}

As market became more and more liberalized during the 1980s, 1990s, and early 2000s, the light touch regulation model came to dominate financial regulators' thinking, which helped to create more liquidity in financial markets, which in turn fueled imprudent lending behavior and created lending bubbles. A vicious cycle was operative, which could definitely lead to a catastrophe.

\section{Systemic Risk:-}

Highly liberalized, highly liquid and globally integrated financial markets easily created more systemic risk if particular kinds of regulations were repealed. For example, the Glass-Steagall Act in the US is a piece of financial regulation that was put in place right after the Great Depression. Many countriesfollowed suit and fabricated their own versions of the Glass-Steagall Act. And in order to protect commercial banking from risks in investment banks, there's a kind of global Glass-Steagall Act playing out in different markets.

However in the 1980s as the US and the UK led a charge to deregulate financial markets and abandoned their own Glass-Steagall Act, other countries followed the herd. They also deserted other kinds of depression error financial regulations that were designed to act as circuit breakers to keep parts of the financial system separate from one another. This repeal itself didn't cause the crisis but it created more systemic risks, making it easier fordifficulties to 
spread among sectors of the financial system. So systemic risks associated with financial liberalization is part of the environment in the years leading up to crisis.

\section{Regulatory Lag:-}

Regulations of financial markets always lag behind the innovation in the market due to the dynamic, fast-moving and competitive characteristic of the market. Liberalization speeds all these up because it makes markets more competitive and contrives more incentives for "actors" in those markets to mold products and instruments to trade. Yet, the regulation to those products and instruments is a slow process because one has to go through the whole political process. So as market became more liquid, integrated, liberalized after 1980s, more and more regulatory lag made the derivative and collateralized debt markets to take off without any oversight of the market. Thus that regulatory lag effect also gave birth to a kind of hole in the old mechanism that allowed some very risky activities to flourish in these markets.

\section{Inadequacy of a Global Oversight:-}

During the global crisis, Basel II and Basel III were implemented by the Bank for International Settlements (BIS), which aimed to encourage banks to be more conservative in their risky assessment model and to increase the international standards of the amount of capital that banks need to hold against its risky portfolios.

However it was very hard for national policy makers, especially those from big countries who were used to have a lot of independent authority to accept the idea of adhering to global regulations. They weren't able to agree on the process that would give the BIS any actual regulatory or enforcement capacity. And banks themselves didn't have individual incentives abiding by those Basel norms, so they came to the conclusion that went back to "this time is different" argument or the "the turkey before Thanksgiving". Hence lack of a global oversight "added fuel to the fire".

\section{Inherent Defect of International Accounting Standards (IAS):-}

The IAS 39 stipulated that financial actors valued assets based on assets' present market value. Wade(2008) argued that this standard formed a kind of proclivity, which means that it magnified the swings by making a boom bigger and a bust server. The reason why IAS 39 is thought as proclivity and playsa role in the crisis is that during the time of a boom, as asset's values were rising, that made the balance sheet of firms and investors look much better because they got the inflated value of all the different assets that they earned, and that made it easier to borrow more and to get credits at a lower cost. Then when the bubbles burst, things got harder because those assets rapidly lost value and had to be then reported at that current very low value, making it more difficult to get credits and to raise capital because the balance sheet looked terrible.

\section{Moral Hazard:-}

Moral hazards exist where more increased risk-taking competition stimulated by regulations in the financial market is involved. The economist John Taylor (2009) maintained that the greater the regulation of the financial market was, the riskier the activities in those markets were. Take the government bail out in the US as an example. The bail out actually created a perverse incentive for firms to take more risks as they became aware that they would receive assistance from the government if they engaged in riskier activities (Taylor, 2009). So rather than discouraging risky behavior, the bail out actually encouraged it.

Based on Efficient Market Hypothesis, some neoclassical economists claimed that there is no need for further regulations providing there is transparent and actual information about the risk of assets. Taleb and Blyth(2011) regarded regulations as poorly designed in the financial market because regulators themselves don't have any skin in the game, that is, they don't bear any consequences when they make mistakes. Wherefore the moral hazard derived from regulations is a catalyst for the financial calamity.

\section{Political Factors:- \\ Revolving Door:-}

The revolving door refers to the movement of personnel between regulators and financial firms which establish an unhealthy relationship between the private sector and governments in the US, creating all the preserve incentives that also help to promote the light touch regulation. 


\section{Powerful Actors:-}

Johnson argued that powerful actors have been able to promote financial legalization both domestically and internationally and he used IMF as an example to elaborate that idea. Internationally IMF promotes financial openness in developing countries that don't have a mature financial system to handle the challenges of systemic risks. Domestically there is a shift of the balance of power as economy shifts more toward financial interests when financial markets become more deregulated and open. Thus financial sector becomes so powerful that there is a kind of shift in priority of what is good for financial sectors tends to be good for the economy as whole, which is definitely not true for any policy.

\section{Ideological Factors:-}

Ideology of light-touch regulation becomes global after the 1980s. Related to that is the spread of the ideology of the self-disciplined and self-governance in finance, that is to say, individual players in financial markets and financial firms should conduct their own oversight and risk assessment, so regulators really don't need to do anything.

Another dominant ideology is the view that the financial interest represents national interests as Johnson argued, namely, what is good for the financial market is also good for the whole economy. And that also helps explain the rationale of light-touch regulation and regulatory discipline.

"This time is different" argument came to associate with the idea of "the great moderation" declared by Ben Bernanke in 2004, saying how economy had changed and business cycle had been moderated, thus there is no longer any reason to think about dramatic swings of the economy. The ideology of "things has fundamentally changed" helped to provide rationale for the argument that assets' price can only go up instead of going down that fuels bubbles and ultimately leads to crisis.

Home ownership is an important value seen as the market of middle classes in the US. This ideology helps to promote the view that everyone should own a home even if they can't afford it. So the view that banks should lend money easily in order to facilitate home ownership for American citizens helps to fuel the housing and subprime bubbles.

One last ideational factor has to do with the big intellectual shift that took place for the general public, the policy community, the bank managers and other actors in the market. That is what is inherently complex, non-linear and unpredictable comes to be seen as knowable and predictable.

\section{Sociological Factors:-}

As I discussed before, Keynes talked about noneconomic motives - "animal spirits" that characterize traders and investors, and regarded many decisions made by investors as a result of animal spirits especially in a world of uncertainty. In other words, the global financial crisis sprang from the irrational, shortsighted and wrong decisions, from the changing level of confidence, from jealousy, hatred and all kinds of sentiments, from perceptions, confusions and illusions, and particularly from the changing news in the market.

\section{Reflection and Concluding Remarks:-}

Reflecting on the past evidence from 1983 bank bailouts to "Greenspan put", we found that policies responding to crisis had always produced side effects and undesired outcomes. Complex systems like the economy need some dose of disorder to develop anti-fragility yet the policy makers have often aimed for maximum stability by artificially suppressing volatility, making the system extremely fragile while exhibiting no visible risks at the same time (Taleb and Blyth, 2011). So the government and central banks should limit their interventions onimportant matters and function more like an emergency room for an economy that is truly sick. In addition, all the factors such aseconomic, regulatory, political, ideological, sociological, etc. must be holistically viewed, and measures concerned with all these factors should be taken in advancein order to prevent the global financial crisis from breaking out anew. 


\section{References:-}

1. Bernanke, B. (2004).'Fedspeak' at the meetings of the American Economic Association, San Diego, California, January 3.

2. Crotty, J. (2009). Structural causes of the global financial crisis: a critical assessment of the "new financial architecture'. Cambridge Journal of Economics. 33, 563-580.

3. Keynes, J. M. [1936] 1973.Volume VII.The General Theory of Employment, Interest and Money. London: Macmillan.

4. Reinhart, C. M. \& Rogoff, K. S. (2009).The aftermath of financial crises.NBER WORKING PAPER SERIES, Working Paper No. 14656.http://www.nber.org/papers/w14656.pdf

5. Skidelsky, W. (2008).Gourmet London.Authentik.

6. Taleb, N. N. \& Blyth, M. (2011). The black swan of Cairo- How suppressing volatility makes the world less predictable and more dangerous. Foreign Affairs. May/June, pp. 33-39.

7. Taylor, J. B.(2009). The financial crisis and the policy responses: An empirical analysis of what went wrong. NBER WORKING PAPER SERIES, Working Paper 14631. http://www.nber.org/papers/w14631.

8. Wade, R. 2008. Financial Regime Change. New Left Review.53, September - October, pp. 5-21 